Handmaidens of the Lord 
Publications of the American Folklore Society

New Series

General Editor, Larry Danielson 


\section{Handmaidens of the Lord}

PENTECOSTAL WOMEN PREACHERS AND TRADITIONAL RELIGION

Elaine J. Lawless

UNIVERSITY OF PENNSYLVANIA PRESS

Philadelphia 
A shorter version of Chapter $\mathbf{5}$ appeared as "Piety and Motherhood:

Reproductive Images and Maternal Strategies of the Woman Preacher," Journal of American Folklore 100 (Oct.-Dec. 1987):469-79. Used by permission.

Maps pp. x-xii used by permission of University of Oklahoma Press.

Copyright $\mathbb{C} 1988$ by Elaine J. Lawless

All rights reserved

Library of Congress Cataloging-in-Publication Data

Lawless, Elaine J.

Handmaidens of the Lord : Pentecostal women preachers and traditional religion / Elaine J. Lawless.

p. $\quad \mathrm{cm} .-$ (Publications of the American Folklore Society ;

new ser.)

Bibliography: $p$.

Includes index

ISBN 0-8122-8100-4. ISBN 0-8122-1265-7 (pbk.)

1. Women clergy-Missouri. 2. Pentecostal churches-MissouriClergy. 3. Missouri-Religious life and customs. I. Title.

II. Series.

BV676.L39 1988

$289.9^{\prime} 4^{\prime} 088042-\mathrm{dc} 19$

Second paperback printing 1994 
For Buena

And in loving memory of

Ellen Ryan Dubinski

who greatly enriched the lives

of all who knew her 
And it shall come to pass afterward, that I will pour out my spirit upon all flesh; and your sons and your daughters shall prophesy, your old men shall dream dreams, your young men shall see visions.

And also upon the servants and upon the handmaids in those days will I pour out my spirit.

[Joel 2:28-29]

Let your women keep silence in the churches: for it is not permitted unto them to speak; but they are commanded to be under obedience, as also saith the law.

And if they will learn any thing, let them ask their husbands at home: for it is a shame for women to speak in the church.

[I Corinthians 14:34-35]

Let the woman learn in silence with all subjection.

But I suffer not a woman to teach, nor to usurp authority over the man, but to be in silence.

For Adam was first formed, then Eve.

And Adam was not deceived, but the woman being deceived was in the transgression.

[I Timothy 2:11-14] 